Al-Atti Amer,

post-graduate student, Interregional Academy of Personnel Management, 03039, Kyiv, Str. Frometivska, 2, tel.: (093) 87100 48, email: Olga_2006@bigmir.net

ORCID: 0000-0002-6094-8368

Аль-Атті Амер,

аспірант, Міжрегіональна Академія управління персоналом, 03039, м. Київ, вул. Фрометівська, 2, тел.: (093) 8710048 , email:Olga_2006@bigmir.net

ORCID: 0000-0002-6094-8368

Аль-Атти Амер,

аспирант, Межрегиональная Академия управления персоналом, 03039, г. Киев, ул. Фрометовская, 2, тел.: (093) 8710048 , email:Olga_2006@bigmir.net

ORCID: 0000-0002-6094-8368

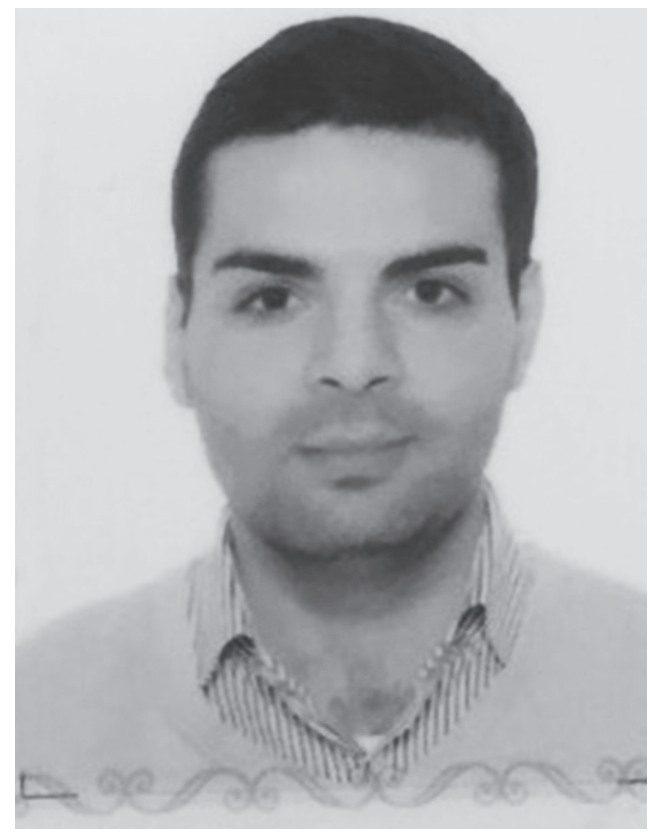

\title{
CONCEPTUAL BASES AND THEORETICAL APPROACHES TO THE DETERMINATION OF THE PUBLIC ADMINISTRATION OUTSTRIPS ECONOMIC DEVELOPMENT OF UKRAINE
}

\begin{abstract}
The article defines conceptual foundations and theoretical approaches to public administration of outstripping development in the Ukrainian economy. Proposed own author's definition of public administration of the outstripping development of the country's economy. By analyzing the consequences of the global crisis, scientists in the public, business and academic circles of Ukraine are increasingly aware that effective development of the national economy in the future is impossible without the resolution of overdue structural problems, especially those of national significance. These are the problems of national competitiveness, the low level of efficiency of use of raw materials and energy resources, the presence of depressed industries, sub-sectors and regions, the placement of capital investments mainly in the sphere of circulation, and not production of goods, etc. Important conclusions are drawn about the uneven and asymmetric effects of globalization on economic development in Ukraine, where, along with positive effects, there are obvious negative effects that can suppress national economic development. It is noted that the tendency of openness of the majority of world economies in different groups of countries of the world is uneven in inten-
\end{abstract}


sity and subject to various factors. Therefore, Ukraine deserves to abandon the given apology of export-oriented development and actualize domestic demand, especially in the areas of high technology and diversification of the export structure itself, in order to significantly increase the share of high-tech goods and services and expand participation in international cooperation of production. It is proved that the export-raw material type of economic growth and the overcentralization of financial resources in the metropolitan metropolis intensify territorial disproportions. The country faced an extremely serious task of reviewing the regional economic policy.

Keywords: public administration, outstripping the development of the economy.

\section{КОНЦЕПТУАЛЬНІ ЗАСАДИ ТА ТЕОРЕТИЧНІ ПІДХОДИ ДО ВИЗНАЧЕННЯ ПУБЛІЧНОГО УПРАВЛІННЯ ВИПЕРЕДЖАЮЧИМ РОЗВИТКОМ ЕКОНОМІКИ УКРАЇНИ}

Анотація. Визначено концептуальні засади та теоретичні підходи до публічного управління випереджаючим розвитком економіки України. Запропоновано власне авторське визначення публічного управління випереджаючим розвитком економіки країни. Аналізуючи наслідки світової кризи, у державних, бізнесових і наукових колах України вчені все більше усвідомлюють, що ефективний розвиток національної економіки у подальшому неможливий без розв'язання назрілих структурних проблем, особливо тих, які мають загальнонаціональне значення. Це проблеми національної конкурентоспроможності, низький рівень ефективності використання сировинних та енергоресурсів, наявність депресивних галузей, підгалузей та регіонів, розміщення капітальних вкладень переважно у сферу обігу, а не виробництво товарів тощо. Зроблено важливі висновки про нерівномірний та асиметричний вплив глобалізації на економічний розвиток в Україні, де поряд із позитивними наслідками є й очевидні негативні ефекти, здатні пригнічувати національний економічний розвиток. Відзначено, що тенденція зростання відкритості більшості економік світу у різних групах країн світу є неоднаковою за своєю інтенсивністю та підпорядковується різноманітним чинникам. Тому Україні доцільно відмовитися від заданої апології експортноорієнтованого розвитку й актуалізувати внутрішній попит, насамперед у сферах високих технологій та диверсифікації самої експортної структури для значного збільшення частки високотехнологічних товарів і послуг та розширення участі у міжнародній кооперації виробництва. Доведено, що експортно-сировинний тип економічного зростання і надцентралізація фінансових ресурсів у столичному мегаполісі підсилюють територіальні диспропорції. Перед країною постало надзвичайно серйозне завдання перегляду регіональної економічної політики.

Ключові слова: публічне управління, державне управління, випереджаючий розвиток економіки. 


\section{КОНЦЕПТУАЛЬНЫЕ ОСНОВЫ И ТЕОРЕТИЧЕСКИЕ ПОДХОДЫ К ОПРЕДЕЛЕНИЮ ПУБЛИЧНОГО УПРАВЛЕНИЯ ОПЕРЕЖАЮЩЕГО РАЗВИТИЯ ЭКОНОМИКИ УКРАИНЫ}

Аннотация. Определены концептуальные основы и теоретические подходы к публичному управлению опережающим развитием экономики Украины. Предложено собственное авторское определение публичного управления опережающим развитием экономики страны. Анализируя последствия мирового кризиса, в государственных, деловых и научных кругах Украины ученые все больше осознают, что эффективное развитие национальной экономики в дальнейшем невозможен без решения назревших структурных проблем, особенно тех, которые имеют общенациональное значение. Это проблемы национальной конкурентоспособности, низкий уровень эффективности использования сырьевых и энергоресурсов, наличие депрессивных отраслей, подотраслей и регионов, размещение капитальных вложений преимущественно в сферу обращения, а не производство товаров и тому подобное. Сделаны важные выводы о неравномерном и асимметричном влиянии глобализации на экономическое развитие в Украине, где наряду с положительными последствиями есть и очевидные негативные эффекты, способные подавлять национальное экономическое развитие. Отмечено, что тенденция роста открытости большинства экономик мира в разных группах стран мира неодинакова по своей интенсивности и подчиняется разнообразным факторам. Поэтому Украине целесообразно отказаться от заданной апологии экспортноориентированного развития и актуализировать внутренний спрос прежде всего в сферах высоких технологий и диверсификации самой экспортной структуры для значительного увеличения доли высокотехнологичных товаров и услуг и расширения участия в международной кооперации производства. Доказано, что экспортно-сырьевой тип экономического роста и сверхцентрализация финансовых ресурсов в столичном мегаполисе усиливают территориальные диспропорции. Перед страной встала чрезвычайно серьезная задача просмотра региональной экономической политики.

Ключевые слова: публичное управление, государственное управление, опережающее развитие экономики.

Target setting. The transition from state to public administration forms new challenges and approaches to the adoption of management decisions, the functioning of the state system itself. The main element in the country's development is the economy. Advancing development of the country's economy is a prerequisite and a guarantee of ensuring competitive advantages in international relations, ensuring innovation and investment growth, as well as a high standard of living for the population.

Analysis of recent publications on issues. The source of information for writing an article is the publications 
and works of scientists on the chosen subject of the study [1-12].

The purpose of the article. The purpose of this article is to determine the conceptual framework and theoretical approaches to public administration of outstripping development in the Ukrainian economy and to propose the own definition of public administration as a outstripping development of the country's economy.

The statement of basic materials. The formation of the Public Administration in Ukraine as a branch of science was preceded by the "State Administration", which was launched in 1997 as a newly created branch "State Administration" and included by the Order of the High Qualifications Commission of Ukraine № 86 dated March 13, 1997, to the List of Scientific Specialties. Further development of science was determined by the specialty and their passports, magistracy, postgraduate and doctoral studies were opened for training in the relevant specialties in state administration, specialized academic councils, professional publications were created, research work was organized that formed theoretical and methodological foundations and infrastructure for science "State Administration" [11]. Scientific directions are devoted to the study of the theory and history of state administration, the mechanisms of state administration, civil service and local self-government.

According to the encyclopedia of state administration, State managementis the activity of the state (bodies of state power) aimed at creating conditions for the most complete realization of state functions, fundamental rights and freedoms of citizens, harmonization of various groups of interests in society and between the state and society, ensuring social development relevant resources [5, p. 157].

G. Atamanchuk believes that state management is a practical, organizing and regulating influence of the state (through the system of its structures) on the social and private life of people in order to organize, preserve or transform, based on its power [1, p. 33].

V. Bakumenko defines state management as a system, where, like any social formation, it consists of functionally united elements (subsystems) with specific properties that determine their place in the structure of this system [2].

V. Martynenko determines that state management is a process of authoritarian governance through the formation and implementation of a state bodies system of executive power at all levels of the administrative-territorial division in the country, which uses a set of methods, mechanisms, power influence on society methods [8, p. 21].

Many researchers (scholars) and practitioners in state management have considered various aspects of the state management mechanisms, numerous works devoted to conceptual aspects: the essence of the concept, principles of construction, tools, types, features, etc.

With regard to public administration, it is a new concept that is just beginning to enter the scientific concept vehicle, and, above all, due to the emergence of a new field of education "Public Management and Administration", which reformed the field of knowledge "State management".

Regarding the sphere of activity, public administration in Ukraine today 
took the position of state management and takes into account such a component as a civil society. Namely, the participation of civil society in the adoption of public-management decisions, which, ideally, is the adoption of these decisions by society itself. If it believes Ukrainian scientist O. Chervyakovoï [11] "Institutions of public administration and civil institutions have subjectsubjective interaction through a regulator. The regulator in this case is a tool that adjusts, corrects and regulates the subject-subject relations in the feedback mechanism. For example, the regulator can be: the regulatory framework (international acts, laws of Ukraine, decrees of the President of Ukraine, the CMU resolutions and other regulations); standards (international, state, industry, enterprises, norms, rules, requirements, etc.); resources (natural, material, financial, labor), as well as individual instruments of government, public and supra-state organizations (treaties, programs and, even, interpersonal relations)" [11].

In the framework of our study, we will consider in more detail the theoretical approaches to the definition of the public administration outstrips economy development of Ukraine.

Thus, in the opinion of O. Moskalenko in the paper "Advancing economic development: theoretical and institutional principles and problems of implementation in Ukraine" [9], advance economic development is defined as a guarantee of the country's securing in international relations the advantages of individual economic, social and political life, as well as a means of preservation and creation of "stock of dominance", competitive advantages in the latest technologies and techniques, methods of public administration, social institutions. Thus, advance economic development can be seen as a mechanism for creating conditions for development on the basis of technological leap and social "elevator". An important element for the country's advanced economic development is determining the social processes of "unity" and "identity" that can form a sense of common, public interest. Such a feeling contributes to the formation of a model of "inclusiveness", which, in turn, contributes to the sustainability of the country's economic system. The constituent models of a pre-eminent economic development are the laws and principles of functioning (in particular, the law of progressing development of human potential, the law of the advanced development of science and education), where the role of the government is sufficiently high in providing innovation-intensive type of economic growth and high quality of human life [9].

Y. Zaitsev, in the article "Advancing economic development as a substantial basis of a modern competitive economy" [6] considers progressive economic development as innovative competition, innovative entrepreneurship, innovative economic policy, innovative (creative, complex, intellectual) labor, innovative motivation for such labor, entrepreneurship, politicians. The publication [6] also states that it is not possible to achieve competitive advantages on the basis of a pre-eminent economic development beyond the framework of the maximum possible, in certain specific conditions, of the functioning of economic and social systems, of innovative value motives of entrepreneurs and 
other economic entities. Above all, it is all the more impossible to ensure that things are ahead of development. According to Y. Zaitsev, the urgent need for the existence of any country in a globalized world as a powerful player in the whole spectrum of international relations and a guarantor of the continued growth of the well-being of its citizens is the study, comprehension and use of the essence, functions and the role of advance economic development in providing sustainable advantages. the national economic system, its separate subjects, in a competitive struggle with the development of society and the state, the use of institutional capacity of the state to create a real motivational mechanism of this type of development.

In the publication of $\mathrm{K}$. Yagelska "Factors of the Forerunner Economic Development" [7] noted the existence of its own strategy of economic development based on the innovation-investment approach, taking into account the socio-economic features of the country and timely identified promising areas. This mechanism is possible in the presence of such factors as political stability, minimization of procyclicality of politics; active state regulation of economic processes with the orientation of reforms for saving and accumulation of capital, creating an attractive investment climate; transparency and availability of the banking system; state support for national economic development (simplification of bureaucratic procedures and tax pressure, stimulation of entrepreneurial activity, venture business); stimulation of scientific and technological development (financing of research activities, fiscal stimulation of investment and innovation activity of enterprises, development of new high technological facilities, modernization of traditional branches); manufacture and export of high-tech products; actively involved in the component of cultural traditions, the system of spiritual and moral values (the transition society consumption to the post-industrial, information society); motivation for work; a flexible educational system that meets the strategic objectives of the country, investment in human capital, technological development of society [7, p. 276-282].

A number of scientists A. Alimov, A. Danilenko, V. Tregobchuk, etc. In the work "Economic Development of Ukraine: Institutional and Resource Support" [4] believe that the creation of favorable institutional conditions and proper resource provision, that is, the formation of an appropriate institutional and resource potential is a necessary condition for the stable economic development of Ukraine [4, p. 501]. For public management of outstripping development of the economy, the authors define a system of interrelated actions on the part of state authorities, namely [4, p. 501-507]: improving the institutional system of Ukraine, increasing financial capital and resources, developing in the industry markets and infrastructure. Among the institutional factors hampering the economic development of Ukraine, the main ones are the low protection of investors' rights and interests, the almost complete absence of an independent court and the non-observance of the rule of law; high political risks of investment (the risk of arbitrary withdrawal of income and capital by the state) significant transaction costs associated with the 
protection of property rights and business. Proceeding from this, the most important tasks of institutional provision for stable economic development of Ukraine should be the elimination of a hidden and sometimes legalized excessive and unreasonable state "patronage" over certain business structures close to the authorities whose revenues are often a source of financing for different political forces, from the latter, lobbying for their interests in government bodies, introducing control from the institutions of civil society (unhindered access to information on the financial situation and activities of government bodies), compliance, and not only declaring, the policy of separating power from business as the most important prerequisite for overcoming corruption.

For the development of Ukraine's economy, the necessary condition, according to scientists, should be the achievement of sustainable development through the activation of internal factors of economic development, and in the integration aspirations necessarily should be fully taken into account national economic interests. Of the internal factors of development, one of the most important is the investment and innovation [4, p. 503].

And for the outstripping development in the Ukrainian economy, one of the primary tasks of the state economic policy should be the transition to the development model, where priority will be given to investing in socially significant projects in such areas as human capital development, resource saving, innovative activity, the revival and modernization of fund-building industries [4, p. 504].
In the work of V. Geets, L. Shinkaruk, T. Artemova and other well-known Ukrainian scholars [10], the main directions and methods of implementing progressive structural transformations in the Ukrainian economy are substantiated. Analyzing the consequences of the global crisis, in the state, business and scientific circles of Ukraine, scientists are increasingly aware that effective development of the national economy in the future is impossible without solving structural problems, especially those that are of national importance. These are the problems of national competitiveness, the low level of efficiency in the use of raw materials and energy resources, the presence of depressed industries, sub-sectors and regions, the placement of capital investments primarily in the sphere of circulation, and not the production of goods and the like. Important conclusions have been drawn about the uneven and asymmetric influence of globalization on economic development in Ukraine, where, along with positive consequences, there are obvious negative effects that can suppress national economic development. Scientists have analyzed trends in the growth of openness in most economies of the world, this process varies in different groups of countries of the world in its intensity and is subject to various factors. Therefore, it is advisable for Ukraine to abandon the given apology for export development and to actualize domestic demand, especially in the areas of high technology and diversification of the export structure itself, to significantly increase the share of high-tech goods and services and expand participation in international production cooperation. It is proved 
that the export-raw type of economic growth and the super-centralization of financial resources in the metropolitan metropolitan area intensify territorial imbalances. The country faces an extremely serious task of viewing regional economic policy [10, p. 12].

T. Burma, E. Makazan, K. Marinova in the publication "Economic integration of Ukraine into the world economy on the basis of the doctrine of advanced development" [3] determine that at the moment in Ukraine there is no state infrastructure necessary to apply the concept of advanced development, cardinal improvement (re-engineering) of the institutional structures of the state, but thanks to the concept it is possible to start reforming the infrastructure of the state in the near future, will allow Ukraine to become full participant in the world integration processes.

Conclusions. Thus, the outstripping development in the Ukrainian economy is considered by scientists as an innovative economic policy of the state on the basis of the development of high-tech industries for participation in international cooperation of production by activating internal factors of economic development and creating an attractive investment climate and state support (motivation) for the development of human potential, science and education.

Therefore, public administration the outstripping development in the country's economy can be defined as a mechanism of innovation economic policy of the state, which creates competitive advantages in the high-tech sector and social institutions, based on the principles of motivation for the development of human potential, science and education, taking into account the socio-economic features of the country.

\section{REFERENCES}

1. Atamanchuk G. (2006), Teoryya hosudarstvennoho upravlenyya: kurs lektsyy [Theory of Public Administration: course of lectures]. $-4^{\text {th }}$ ed., Supplement, Omega-L, Moscow.

2. Bakumenko V., Nadolishniy P. (2003), Teoretychni ta orhanizatsiyni zasady derzhavnoho upravlinnya: Navch. Posibnyk [Theoretical and organizational principles of public administration: Teaching. Manual], Millennium, Kyiv. - P. 113-122, 128-130.

3. Burma T., Makazan Y., Marynova K. (2014), "Ekonomichna intehratsiya Ukrayiny $\mathrm{v}$ svitovu ekonomiku na osnovi doktryny vyperedzhayuchoho rozvytku" ["Economic integration of Ukraine into the world economy on the basis of a doctrine of advanced development"], Aktual'ni problemy upravlinnya ta finansovo-hospodars'koyi diyal'nosti pidpryyemstva. - № 46 (1089). - P. 20-25.

4. Alymov O., Danylenko A., Trehobchuk A. and others. (2005), Ekonomichnyy rozvytok Ukrayiny: instytutsional'ne ta resursne zabezpechennya [Economic development of Ukraine: institutional and resource support], Ob'yednanyy in-tekon. NAN Ukrayiny, Kyiv, Ukraine.

5. Entsyklopediya derzhavnoho upravlinnya (2011), [Encyclopedia of Public Administration], T. 1. Teoriya derzhavnoho upravlinnya, NADU, Kyiv, Ukraine.

6. Zaytsev Y. (2014), "Vyperedzhayuchyy ekonomichnyy rozvytok yak substantsional'na osnova suchasnoyi konkurentnoyi ekonomiky" ["Advancing economic development as a substantial basisofamoderncompetitiveeconomy"]. Teoretychni doslidzhennya Ukrayiny: aspekty pratsi. - № 1. - P. 16-21. 
7. Kendyukhov O., Yagelska K. (2013), "Chynnyky vyperedzhayuchoho ekonomichnoho rozvytku" [Factors of the Outlying Economic Development], Visnyk ekonomichnoyi nauky Ukrayiny. - № 2 (24). - P. 47-51.

8. Martynenko V. (2003), Derzhavne upravlinnya: shlyakh do novoyi paradyhmy (teoriya ta metodolohiya) [Public Administration: The Way to a New Paradigm (Theory and Methodology)], Mahistr, Kharkiv, Ukraine.

9. Moskalenko O. (2014), "Vyperedzhayuchyy ekonomichnyy rozvytok: teoretyko-instytutsional'ni zasady i problemy realizatsiyi v Ukrayini” [Advancing economic development: theoreticalinstitutional principles and problems of realization in Ukraine], Ekonomika Ukrayiny. - № 8. - P. 4-18.

10. Geets V., Shynkaruk L., Artyomova T. and others. (2011), Strukturni zminy ta ekonomichnyy rozvytok Ukrayiny [Structural changes and economic development of Ukraine], Ob'yednanyy in-tekon. NAN Ukrayiny, Kyiv, Ukraine.

11. Cheroyakova O. (2017), "Nova paradyhma oriyentyriv publichnoho upravlinnya" [The New Paradigm of the Guidelines for Public Administration], Naukovi zapysky Instytutu zakonodavstva Verkhovnoyi Rady Ukrayiny, № 1/2017. - P. 171-175.

12. Yagelska K. (2015), Vyperedzhayuchyy natsional'nyy ekonomichnyy rozvytok: teoretyko-metodolohichnyy ta prykladnyy aspekty [Advancing national economic development: theoretical-methodological and applied aspects], Donetsk National Technical University, Kyiv: Tsentr uchbovoyi literatury, Kyiv, Ukraine.

\section{СПИСОК ВИКОРИСТАНИХ ДЖЕРЕЛ}

1. Атаманчук Г. В. Теория государственного управления: курс лекций, 4-е изд., доп. / Г. В. Атаманчук. - М.: Омега-Л, 2006. - 584 с.

2. Бакуменко В. Д., Надолішній П. І. Теоретичні та організаційні засади державного управління: навч. посіб. - К.: Міленіум, 2003. C. 113-122, 128-130.

3. Бурма T. Г. Економічна інтеграція України в світову економіку на основі доктрини випереджаючого розвитку / Т. Г. Бурма, С. В. Маказан, К. Г. Маринова // Вісн. Нац. техн. ун-ту “ХПІ" : зб. наук. пр. темат. вип. : Актуальні проблеми упр. та фінансово-господарської діяльності підприємства. - Харків : НТУ “ХПІ”. 2014. - № 46 (1089). - С. 20-25.

4. Економічний розвиток України: інституціональне та ресурсне забезпечення: монографія / О. М. Алимов, А. І. Даниленко, В. М. Трегобчук та ін. - К.: Об'єднаний ін-т екон. НАН України, 2005. - 540 с.

5. Енииклопедія державного управління. [Текст] у 8 т. - Т. 1. Теорія держ. управління / Нац. акад. держ. упр. при Президентові України; наук.-редкол.: Ю. В. Ковбасюк (гол.) [та ін.]. - К.: НАДУ, 2011. - 747 с.

6. Зайщев Ю. Випереджаючий економічний розвиток як субстанціональна основа сучасної конкурентної економіки / Ю. Зайцев // Теоретичні дослідження, України: аспекти праці. - № 1. - 2014. - С. 16-21.

7. Кендюхов О., Ягельська К. Чинники випереджаючого економічного розвитку / О. Кендюхов, К. Ягельська // Вісн. економ. науки України. 2013. - № 2 (24). - C. 47-51.

8. Мартиненко B. М. Державне управління: шлях до нової парадигми (теорія та методологія) / В. М. Мартиненко. - Харків : Магістр, 2003. $220 \mathrm{c}$.

9. Москаленко О. М. Випереджаючий економічний розвиток: теоретико-інституціональні засади і пробле- 
ми реалізації в Україні / О. М. Москаленко [Електронний ресурс] // Економіка України. - 2014 . № 8. - С. 4-18. - Режим доступу: http://nbuv.gov.ua/UJRN/EkUk_ 2014_8_2

10. Структурні зміни та економічний розвиток України: монографія / [B. М. Геєць, Л. В. Шинкарук, T. I. Артьомова та ін.]; за ред. Л. В. Шинкарук; НАН України; Ін-т екон. та прогнозув. - К., 2011. $696 \mathrm{c.}$.
11. Червякова О.В. Нова парадигма орієнтирів публічного управління / О. В. Червякова // Наукові записки Ін-ту законодавства Верховної Ради України. - № 1/2017 - МП Леся, 2017. - C. 171-175.

12. Ягельська К. Ю. Випереджаючий національний економічний розвиток: теоретико-методологічний та прикладний аспекти : монографія / К. Ю. Ягельська ; ДВНЗ “Донец. нац. техн. ун-т”. - Київ : Центр учбової л-ри, 2015. - 349 с. 